\title{
Prevalance of IgM antibodies to phenolic glycolipid I among household contacts and controls in Korea and the Philippines
}

\author{
SANG-NAE CHO, ${ }^{*}$ SEONG-HWA KIM†, \\ R V CELLONA, $\ddagger$ GERTRUDE P CHAN, $\S$ \\ T T FAJARDO, $\ddagger$ G P WALSH $\ddagger \&$ JOO-DEUK KIM* \\ *Department of Microbiology, Yonsei University College of \\ Medicine, CPO Box 8044, Seoul 100-680, Korea; †Catholic Skin \\ Disease Clinic, Taegu, Korea; $\ddagger$ Leonard Wood Memorial Center for \\ Leprosy Research, Cebu, Philippines; §Department of Immunology, \\ Research Institute for Tropical Medicine, Manila, Philippines
}

Accepted for publication 24 August 1991

\begin{abstract}
Summary Phenolic glycolipid I (PGL-I) is a Mycobacterium leprae-specific antigen and the antibodies to the antigen may suggest an $M$. leprae infection. To compare the $M$. leprae transmission among the populations, we compared the prevalence of anti-PGL-I IgM antibodies among household contacts and controls between Korea and the Philippines. In Korea (prevalence of leprosy-- $0 \cdot 04: 1000$ ), the prevalence of anti-PGL-I antibodies were $4 \cdot 8 \%$ among controls and $8 \cdot 0 \%$ among contacts, respectively. On the other hand, the seroprevalence rate was $10.8 \%$ among controls and $13.4 \%$ among contacts in the Philippines (prevalence of leprosy-- $0 \cdot 70: 1000)$. Interestingly, a marked difference was noted in the prevalance of anti-PGL-I antibodies among children between the countries; 10$14 \%$ among children under 10 years old and $15-18 \%$ among those aged between 10 and 19 in the Philippines compared to $0 \%$ and $2 \cdot 9-6.4 \%$ in Korea, respectively. This study, therefore suggests that a high prevalance of anti-PGL-I IgM antibodies among children may indicate an active transmission of $M$. leprae, resulting in a higher incidence of leprosy in the population.
\end{abstract}

\section{Introduction}

The prevalence or incidence of leprosy has continuously changed in a closed population along with various factors, such as coverage of leprosy control programmes, and socioeconomic status. The recent introduction of multidrug therapy' for leprosy patients is about to bring the incidence of leprosy down further in the near future. However, it has been difficult to determine the $M$. leprae transmission in the community partly due to a lack of specific tools to measure it.

A recent development of a seroepidemiological tool based on the phenolic glycolipid I (PGL-I), ${ }^{2}$ an $M$. leprae-specific antigen, made it possible to detect the $M$. leprae infection 
or exposure to the organism. ${ }^{3-5}$ In the literature, the prevalence of anti-PGL-I antibodies varied from $1 \cdot 0$ to $16 \cdot 0 \%$ among controls ${ }^{6-10}$ in the endemic areas of leprosy, and from 12 to $20 \%$ among household contacts. ${ }^{6-9,11}$ However, few studies focused on the dynamics of $M$. leprae transmission among controls and contacts between countries, and correlated the prevalance of anti-PGL-I antibodies to the incidence and prevalence of leprosy among the populations under study.

This study was thus initiated to compare the seroprevalence among household contacts and controls between Korea, where the incidence of leprosy has declined rapidly, and the Philippines, where the incidence has been stable or only gradually declining during the last two decades. The age-adjusted prevalences of anti-PGL-I IgM antibodies were then compared among household contacts and controls between the countries.

\section{Materials and methods}

\section{STUDY POPULATIONS}

Korea has been an endemic area of leprosy for several centuries; however, since the economics of the country started to improve dramatically late in the $1960 \mathrm{~s}$, there has been a rapid decline in the incidence of leprosy from about 1500 new cases in $1973^{12}$ to 106 cases in $1988 .^{13}$ There were about 25,000 registered cases in a population of 42 million. However, most of the registered patients are inactive and only about 1800 patients (prevalence; $0 \cdot 04: 1000$ ) are still active, i.e. bacteriologically positive with a skin smear. When the characteristics of new patients were analysed, there was also changes in the proportion of clinical types, i.e. only $39 \%$ of new cases were lepromatous in 1973, but about $56 \%$ were lepromatous patients in 1988. Among new cases found in 1988, $72 \%$ were more than 40 years old. Only $1.0 \%$ were under 15 years old, thus indicating that Korean children now have little chance of being exposed to M. leprae. ${ }^{13}$

In the Philippines, there were about 56,000 registered leprosy cases in a population of 55 million in 1986, and about 70\% (38,000 cases) of them were active patients, i.e. BI positive (prevalence; $0 \cdot 70: 1000) .{ }^{14}$ The incidence of leprosy in the urban Manila area was 934 cases in 1978 and slightly decreased to 739 cases in 1986; however, total active cases increased from 6957 cases in 1978 to 11,727 cases in $1986 .{ }^{14}$ Among the new cases, $34 \%$ were lepromatous, $27 \%$ were tuberculoid, and 38\% were borderline, respectively. Interestingly, $10 \cdot 5 \%$ of new cases were under 15 years old, and $27 \%$ were aged between 15 and 24 , thus indicating that the substantial portion of new cases still occur in young age groups. In the Cebu City area, Philippines, there were 348 new cases in 1985, and the distribution of clinical types of new cases were as follows; tuberculoid $41.7 \%$, lepromatous $30 \cdot 2 \%$, borderline $18 \cdot 7 \%$, and indeterminate $9 \cdot 5 \% .{ }^{14}$

\section{SERUM SPECIMENS}

Controls from Korea consisted of 244 children who visited the paediatrics clinic at a teaching hospital in Seoul, where the prevalence of active leprosy patients is about $0 \cdot 03$ : $1000,{ }^{13} 388$ residents from low endemic rural areas (prevalence; 0.02:1000), and 500 residents who were presented for reasons other than leprosy to the Catholic Skin Disease Clinic in the Kyungbuk province, which is one of the provinces with the highest prevalance of leprosy $(0 \cdot 05: 1000)$. Serum samples were also obtained from 1151 
household contacts residing in the resettlement villages scattered throughout the Kyungbuk province.

Normal controls in the Philippines also represented the heterogeneous populations consisting of 304 persons who visited the Skin Clinic of the Leonard Wood Memorial Center for Leprosy Research, Cebu City, for reasons other than leprosy and 300 persons who visited a paediatrics clinic or were blood donors or medical students in the urban Manila area. A total of 365 serum samples were from household contacts of leprosy patients in the Cebu and the Manila area.

\section{DETECTION OF ANTIBODIES TO PGL-I}

An enzyme-linked immunosorbent assay (ELISA) described by Voller et al. ${ }^{15}$ was employed with minor modification as reported previously. ${ }^{3.16}$ However, instead of the native glycolipid, the semi-synthetic neoglycoprotein $O$-(3,6-di- $O$-methyl- $\beta$-D-glucopyranosyl)-( $1 \rightarrow 4)$-(2,3-di- $O$-methyl- $\alpha$-L-rhamnopyranosyl)-( $1 \rightarrow 9)$-oxynonanoyl-bovine serum albumin (natural disaccharide-octyl-BSA; ND-O-BSA) ${ }^{17}$ was used. Briefly, $50 \mu$ of diluted ND-O-BSA (20 ng sugar/ml) in carbonate buffer, $\mathrm{pH} 9 \cdot 6$, was added to the wells of U-bottom microtitre plates (Dynatech Laboratories, Inc., Alexandria, VA, USA), and incubated overnight at $37^{\circ} \mathrm{C}$ in a moist chamber. The wells were then washed with phosphate-buffered saline (PBS) solution, pH 7.4, containing 0.05\% Tween 20 (PBST) and blocked by the addition of $100 \mu$ of PBST-0.05\% bovine serum albumin (BSA) at $37^{\circ} \mathrm{C}$ for $1 \mathrm{~h}$. After emptying the wells, $50 \mu \mathrm{l}$ of serum diluted $1: 300$ in PBST-5\% normal goat serum (NGS) (Gibco Laboratories, Grand Island, NY, USA) was added to the wells which were incubated at $37^{\circ} \mathrm{C}$ for $90 \mathrm{~min}$. After washing the wells, $50 \mu \mathrm{l}$ of affinitypurified peroxidase-conjugated goat anti-human IgM (Behring Diagnostics, San Diego, CA, USA) diluted 1:5000 in PBST-5\% NGS was added and incubation was continued at $37 \mathrm{C}$ for $1 \mathrm{~h}$. After another washing, $50 \mu \mathrm{l}$ of substrate solution, $\mathrm{H}_{2} \mathrm{O}_{2}$-o-phenylenediamine was added to the wells which were incubated at room temperature for about $15 \mathrm{~min}$. The reaction was then stopped with $50 \mu \mathrm{l}$ of $2.5 \mathrm{~N} \mathrm{H}_{2} \mathrm{SO}_{4}$ and the absorbance was read at $490 \mathrm{~nm}$.

Each test was performed in triplicate and the mean absorbance of wells with BSA only was subtracted from those of wells with ND-O-BSA. Six wells in each plate were allocated for a pooled positive control serum, and plate-to-plate and day-to-day variations were adjusted based on the mean absorbance value of the positive control serum. The criteria for the seropositivity was determined by adding $2 \times \mathrm{SD}$ to the mean absorbance of controls, and the absorbance $\geqslant 0.200$ was considered seropositive as reported previously. ${ }^{8}$

\section{Results}

Serum specimens from controls and household contacts from Korea were examined for the presence of anti-PGL-I antibodies using ELISA. Of 1132 controls examined, 54 $(4 \cdot 8 \%)$ had significant anti-PGL-I IgM antibodies (Table 1$)$. The age-specific prevalance was highest among the controls $(10 \cdot 1 \%)$ aged between 20 and 30 years old, and declined with increase in age. It was interesting that none of 206 controls under 10 years old and only $2 \cdot 9 \%$ of controls aged $10-19$ years old were seropositive to PGL-I, thus indicating 
Table 1. IgM seroreactivity to PGL-I in sera from normal controls in Korea

\begin{tabular}{lcrr}
\hline & & \multicolumn{2}{c}{$\begin{array}{c}\text { Seropositive to } \\
\text { PGL-I* }\end{array}$} \\
\cline { 3 - 4 } Age & $\begin{array}{c}\text { No. } \\
\text { assayed }\end{array}$ & No. & $(\%)$ \\
\hline $1-9$ & 206 & 0 & $(0)$ \\
$10-19$ & 104 & 3 & $(2 \cdot 9)$ \\
$20-29$ & 169 & 17 & $(10 \cdot 1)$ \\
$30-39$ & 189 & 13 & $(6 \cdot 9)$ \\
$40-49$ & 167 & 10 & $(6 \cdot 0)$ \\
$50 \leqslant$ & 297 & 11 & $(3 \cdot 7)$ \\
\hline Total & 1132 & $54 \dagger$ & $(4 \cdot 8)$ \\
\hline
\end{tabular}

* Criteria for the seropositivity: $\operatorname{IgM} \mathrm{A}_{490} \geqslant 0 \cdot 200$.

$\uparrow$ Mean \pm SD $\mathrm{A}_{490}$ of the seropositive individuals: $0 \cdot 298 \pm 0 \cdot 101$ (range: $0 \cdot 201-0 \cdot 708$ ).

minimal exposure of young residents to $M$. leprae in Korea. The age-adjusted prevalance of anti-PGL-I IgM antibodies was a little bit higher among controls from the Kyeongbuk province $(5 \cdot 0 \%)$ than from another rural area $(3.4 \%)$ (data not shown), thus reflecting the prevalance of leprosy cases in the rural areas of Korea.

Among the household contacts in Korea, $92(8 \cdot 0 \%)$ of the 1151 samples examined were seropositive to PGL-I (Table 2). The age-specific prevalence was $0 \%$ among contacts under 10 years old and $6.4 \%$ among contacts aged between 10 and 20 years, and was a stable $12-14 \%$ among contacts over 20 years old. The overall prevalence of anti-PGL-I IgM antibodies among contacts was significantly higher than among normal controls $\left(p<0.001, \chi^{2}\right.$ test), thus indicating that household contacts in Korea had more chance of being exposed to the leprosy bacillus.

Serum samples from contacts and controls from the Philippines were also examined

Table 2. IgM seroreactivity to PGL-I in sera from household contacts of leprosy patients in Korea

\begin{tabular}{lrrr}
\hline & & \multicolumn{2}{c}{$\begin{array}{c}\text { Seropositive to } \\
\text { PGL-I* }\end{array}$} \\
\cline { 3 - 4 } Age & $\begin{array}{c}\text { No. } \\
\text { assayed }\end{array}$ & No. & $(\%)$ \\
\hline $1-9$ & 45 & 0 & \\
$10-19$ & 674 & 43 & $(6 \cdot 4)$ \\
$20-29$ & 232 & 28 & $(12 \cdot 1)$ \\
$30-39$ & 83 & 10 & $(12 \cdot 1)$ \\
$40-49$ & 51 & 7 & $(13 \cdot 7)$ \\
$50 \leqslant$ & 66 & 4 & $(6 \cdot 1)$ \\
\hline Total & 1151 & $92 \dagger$ & $(8 \cdot 0)$ \\
\hline
\end{tabular}

\footnotetext{
* Criteria for the seropositivity: $\operatorname{IgM} \mathrm{A}_{490} \geqslant 0 \cdot 200$

+ Mean \pm SD $A_{490}$ of the seropositive individuals: $0 \cdot 383 \pm 0 \cdot 173$ (range: $0 \cdot 200-1 \cdot 030$ ).
} 
Table 3. IgM seroreactivity to PGL-I in sera from normal controls from the Philippines

\begin{tabular}{lcrr}
\hline & & \multicolumn{2}{c}{$\begin{array}{c}\text { Seropositive to } \\
\text { PGL-I* }\end{array}$} \\
\cline { 3 - 4 } Age & $\begin{array}{c}\text { No. } \\
\text { assayed }\end{array}$ & No. & $(\%)$ \\
\hline $1-9$ & 50 & 5 & $(10 \cdot 0)$ \\
$10-19$ & 109 & 16 & $(14 \cdot 7)$ \\
$20-29$ & 129 & 17 & $(13 \cdot 2)$ \\
$30-39$ & 110 & 13 & $(11 \cdot 8)$ \\
$40-49$ & 95 & 6 & $(6 \cdot 3)$ \\
$50 \leqslant$ & 111 & 8 & $(7 \cdot 2)$ \\
\hline Total & 604 & $65 \dagger$ & $(10 \cdot 8)$ \\
\hline
\end{tabular}

$*$ Criteria for the seropositivity: $\operatorname{IgM} \mathrm{A}_{490} \geqslant 0 \cdot 200$.

$\dagger$ Mean $\pm \mathrm{SD} \mathrm{A}_{490}$ of the seropositive individuals: $0 \cdot 382 \pm 0 \cdot 237$ (range: $0 \cdot 201-1 \cdot 511$ ).

for the presence of anti-PGL-I IgM antibodies. The seroprevalence was $10 \cdot 8 \%$ for controls (Table 3 ) and $13.4 \%$ for contacts (Table 4), respectively. There was no significant difference in the prevalence of anti-PGL-I IgM antibodies between household contacts and controls in the Philippines, thus indicating that noncontact controls had the same chance of exposure to $M$. leprae as household contacts in the Philippines. The age-specific prevalence of anti-PGL-I IgM antibodies was also high with $10-14 \%$ among controls and contacts under 10 years old, and peaked at 15-18\% among those aged between 10 and 19 years old, followed by a gradual decline in the older age groups.

To overcome the differences in age distribution between the study populations, the age-adjusted seroprevalence of anti-PGL-I IgM antibodies was calculated based on the

Table 4. IgM seroreactivity to PGL-I in sera from household contacts of leprosy patients in the Philippines

\begin{tabular}{lccc}
\hline & & \multicolumn{2}{c}{$\begin{array}{c}\text { Seropositive to } \\
\text { PGL-I* }\end{array}$} \\
\cline { 3 - 4 } Age & $\begin{array}{c}\text { No. } \\
\text { assayed }\end{array}$ & No. & $(\%)$ \\
\hline $1-9$ & 50 & 7 & $(14 \cdot 0)$ \\
$10-19$ & 94 & 17 & $(18 \cdot 1)$ \\
$20-29$ & 79 & 11 & $(13 \cdot 9)$ \\
$30-39$ & 69 & 6 & $(8 \cdot 7)$ \\
$40-49$ & 54 & 5 & $(9 \cdot 3)$ \\
$50 \leqslant$ & 19 & 3 & $(15 \cdot 8) \dagger$ \\
\hline Total & 365 & $49 \ddagger$ & $(13 \cdot 4)$ \\
\hline
\end{tabular}

* Criteria for the seropositivity: $\operatorname{IgM} \mathrm{A}_{490} \geqslant 0 \cdot 200$.

$\dagger$ The number of samples examined was too small to be compared accurately.

$\$$ Mean $\pm \mathrm{SD} \mathrm{A} 490$ of the seropositive individuals: $0 \cdot 337 \pm 0 \cdot 194$ (range: $0 \cdot 201-1 \cdot 182$ ). 
Table 5. Comparison of age-adjusted prevalence of $\operatorname{IgM}$ antibodies to PGL-I in sera from controls and contacts between Korea and the Philippines*

\begin{tabular}{|c|c|c|c|c|c|c|c|c|c|}
\hline \multirow[b]{3}{*}{ Age } & \multirow{3}{*}{$\begin{array}{c}\text { No. } \\
\text { compared } \dagger\end{array}$} & \multicolumn{4}{|c|}{ Korea } & \multicolumn{4}{|c|}{ Philippines } \\
\hline & & \multicolumn{2}{|c|}{ Controls } & \multicolumn{2}{|c|}{ Contacts } & \multicolumn{2}{|c|}{ Controls } & \multicolumn{2}{|c|}{ Contacts } \\
\hline & & No. & $(\%)$ & No. & $(\%)$ & No. & $(\%)$ & No. & $(\%)$ \\
\hline $1-9$ & 23,800 & 0 & $(0)$ & 0 & $(0)$ & 2,380 & $(10 \cdot 0)$ & 3,332 & $(14 \cdot 0)$ \\
\hline $10-19$ & 22,070 & 419 & $(1 \cdot 9)$ & 1,412 & $(6 \cdot 4)$ & 3,244 & $(14 \cdot 7)$ & 3,995 & $(18 \cdot 1)$ \\
\hline $20-29$ & 19,440 & 1,963 & $(10 \cdot 1)$ & 2,352 & $(12 \cdot 1)$ & 2,566 & $(13 \cdot 2)$ & 2,702 & $(13 \cdot 9)$ \\
\hline $30-39$ & 14,210 & 980 & $(6 \cdot 9)$ & 1,719 & $(12 \cdot 1)$ & 1,677 & $(11 \cdot 8)$ & 1,236 & $(8 \cdot 7)$ \\
\hline $40-49$ & 8,790 & 527 & $(6 \cdot 0)$ & 1,204 & $(13 \cdot 7)$ & 553 & $(6 \cdot 3)$ & 817 & $(9 \cdot 3)$ \\
\hline $50 \leqslant$ & 11,690 & 433 & $(3 \cdot 7)$ & 713 & $(6 \cdot 1)$ & 842 & $(7 \cdot 2)$ & 1,847 & $(15 \cdot 8)_{+}^{+}$ \\
\hline Total & 100,000 & 4,322 & $(4 \cdot 3)$ & 7,400 & $(7 \cdot 4)$ & 11,262 & $(11 \cdot 3)$ & 13,929 & $(13 \cdot 9)$ \\
\hline
\end{tabular}

\footnotetext{
* Criteria for the seropositivity: $\operatorname{IgM} \mathrm{A}_{490} \geqslant 0 \cdot 200$.

$\dagger$ Based on the population of Cebu Island, Philippines.

‡ The sample size was too small to be accurate.
}

age structure of the populations in the Cebu Island, the Philippines. Even after adjusting for age, the prevalance of anti-PGL-I IgM antibodies was $7 \cdot 4 \%$ for contacts, which was significantly higher than that among controls $(4.3 \%)$ in Korea $(p<0.01)$ (Table 5). In the Philippines, however, there was no significant difference in seroprevalence of anti-PGL-I antibodies between controls $(11.3 \%)$ and contacts $(13.9 \%)$, thus indicating that controls and contacts had a similar opportunity for exposure to $M$. leprae.

The seroprevalence among controls and contacts in the Philippines were significantly higher than those in Korea $\left(p<0.001, \chi^{2}\right.$ test). More interestingly, the magnitude of the difference in seroprevalance was greater among controls and contacts under 20 years old (Table 5). In fact, there was no significant difference in the prevalance of anti-PGL-I IgM antibodies among contacts and controls over 30 years old between Korea and the Philippines.

\section{Discussion}

Since PGL-I is an M. leprae-specific antigen, the presence of antibodies to the antigen may reflect exposure to or infection with bacilli. In previous studies, the specificity of the antigen in serological tests ranged from 97 to $100 \%$ against nonendemic controls. ${ }^{3-5}$ The cut-off values used in this study were based on the controls from the Seoul City area, where leprosy is the least prevalent in Korea, and only $1.5 \%$ of the controls exceeded the cut-off value. ${ }^{8}$

With this critera, the seroprevalence of anti-PGL-I IgM antibodies among household contacts and controls in the Philippines was significantly higher than those in Korea. This may reflect the higher prevalence and incidence of leprosy in the Philippines, particularly, the higher seroprevalence among young populations, which strongly suggested that transmission has taken place widely in the community regardless of intimate contacts within the families. Interestingly, household contacts aged over 30 in Korea seemed to 
have a similar chance of $M$. leprae infection to those in the Philippines because the seroprevalences were comparable. This may also indicate that anti-PGL-I IgM antibodies are detectable for 10-20 years or longer after exposure if no treatment is given.

Considering that a rapid decline in the incidence of leprosy occurred during the 1970s, before the introduction of a MDT programme, the reduction of $M$. leprae transmision among controls and contacts in Korea might be partly due to the improvement of the socioeconomic status and individuals' health, because Korea had a faster growing economy than the Philippines over the last two decades. Another possible explanation is that the segregation of leprosy patients in resettlement villages was more effective in Korea, where about half of the registered leprosy patients reside currently in over 100 resettlement villages throughout the country. ${ }^{13}$

Interestingly, there was no significant difference in seroprevalence between contacts and controls in the Philippines, indicating that the general population was equally exposed to the leprosy bacillus. Bagshawe et al. ${ }^{7}$ also reported no significant differences in seroprevalence between controls and household contacts in Papua New Guinea. In the report, controls or contacts under 20 years old had the highest seroprevalence at $25 \%$ compared with $7 \%$ among those over 20 years of age.

One of the limitations of the PGL-I antigen for measuring the degree of $M$. leprae transmission is that the sensitivity is very low (about $30-50 \%$ ) among tuberculoid leprosy patients. $^{3-5}$ Therefore, any prevalence rate of anti-PGL-I IgM antibodies among controls and contacts may reflect only a portion of the individuals infected with $M$. leprae. Even with the limitation, however, this study suggests that the PGL-I based serology may be useful in determining the relative intensity of $M$. leprae transmission among controls and contacts in populations of interest. Particularly, a high seroprevalence among children may indicate high incidence and prevalence of leprosy in the population and the active transmission of $M$. leprae in the community.

\section{Acknowledgments}

This work was supported in part by grants from the UNDP/World Bank/WHO Special Programme for Research and Training in Tropical Diseases, the Korean Science and Engineering Foundation (1990), Seoul, Korea, the Leonard Wood Memorial (American Leprosy Mission), Rockville, Maryland, and the German Leprosy Relief Foundation, Würzburg, Germany. We also thank E O Shin and Y K Lee for technical assistance.

\section{Ref erences}

1 WHO Study Group. Chemotherapy of leprosy for control programmes. WHO: Geneva, 1982.

2 Hunter SW, Brennan PJ, A novel phenolic glycolipid from Mycobacterium leprae possibly involved in immunogenicity and pathogenicity. J Bacteriol, 1981; 147: 728-35.

${ }^{3}$ Cho SN, Yanagihara DL, Hunter SW, Gelber RH, Brennan PJ. Serological specificity of phenolic glycolipid I from Mycobacterium leprae and use in serodiagnosis of leprosy. Infect Immun, 1983; 41: 1077-83.

4 Young DB, Buchanan TM. A seriological test for leprosy with a glycolipid specific for Mycobacterium leprae. Science, 1983; 221: 1057-9.

5 Brett SJ, Draper P, Payne SN, Rees RJW. Serological activity of a characteristic phenolic glycolipid from Mycohacterium leprae in sera from patients with leprosy and tuberculosis. Clin exp Imm, 1983; 52: 271-9.

${ }^{6}$ Chanteau S, Cartel J-L, Guidi C, Plichart R, Bach M-A. Seroepidemiological study on 724 household 
contacts of leprosy patients in French Polynesia using disaccharide-octyl-BSA as antigen. Int J Lepr, 1987; 55: $626-32$.

7 Bagshawe AF, Garsia RJ, Baumgart K, Astbury L. IgM serum antibodies to phenolic glycolipid-I and clinicalleprosy: two years' observation in a community with hyperendemic leprosy. Int J Lepr, 1990; 58: 2530.

8 Cho SN, Shin JS,. Choi IH, Kim SH, Kim DI, Kim JD. Detection of phenolic glycolipid I of Mycobacterium leprae and antibodies to the antigen in sera from leprosy patients and their contacts. Yonsei Med J, 1988; 29: 219-24.

9 Hussain R, Jamil S, Kifayet A, Firdausi F, Dockrel HM, Lucas S, Hasan R. Quantitation of IgM antibodies to the M. leprae synthetic disaccharide can predict early bacterial multiplication in leprosy. Int J Lepr, 1990; 58: 491-502.

10 Roche PW, Britton WJ, Failbus SS, Williams D, Pradhan HM, Theuvenet WJ. Operational value of serological measurements in multibacillary leprosy patients: clinical and bacteriological correlates of antibody responses. Int $J$ Lepr, 1990; 58: 480-90.

11 Gonzalez-Abreu E, Mora N, Perez M, Pereira M, Perez J, Gonzalez AB. Serodiagnosis of leprosy in patients' contacts by enzyme-linked immunosorbent assay. Lepr Rev, 1990; 61: 145-50.

12 Korean Leprosy Control Association. Annual Report 1983; Anyang, Korea.

13 Korean Leprosy Control Association. Annual Report 1989, Anyang, Korea.

14 Romero RC. Leprosy in the Philippines. Philippine Council for Health Research and Development, Technical Reports Series No. 4, Manila, Philippines, 1988.

15 Voller A, Bidwell DE, Bartlett A. The enzyme-linked immunoassay (ELISA). Alexandria, Va., Dynatech Laboratories, Inc., 1979.

16 Cho SN, Cellona RV, Fajardo TT, Jr., Abalos RM, dela Cruz EC, Walsh GP, Kim JD, Brennan PJ. Detection of phenolic glycolipid-I antigen and antibody in sera from new and relapsed lepromatous patients treated with various drug regimens. Int J Lepr, 1991; 59: 25-31.

17 Chatterjee D, Douglas JT, Cho SN, Rea TH, Gelber RH, Aspinall GO, Brennan PJ. Chemical synthesis and seroreactivity of $O$-(3,6-di- $O$-methyl- $\beta$-D-glucopyranosyl)-( $1 \rightarrow 4)-O$-(2,3-di- $O$-methyl- $\alpha$-L-rhamnopyranosyl)-disaccharide-octyl-neoglycoprotein. Carbohydr Chem, 1986; 156: 39-56. 


\title{
Fréquence des anticorps IgM glycolipide phénolique I, chez des sujets d'un même
} foyer en contact avec l'infection et chez des témoins, en Corée et aux Philippines

\author{
Sang-Nae Cho, Seong Hwa-Kim, R V Cellona, Gertrude P Chan, \\ T Fajardo, G P Walsh et Joo-Deuk Kim
}

Résumé Le glycolipide phénolique I (PGL-I) est un antigène spécifique de $M$ ycobacterium leprae et les anticorps antigène semblent indiquer une infection à $M$. leprae. Pour apprécier la transmission de $M$. leprae parmi les populations, nous avons comparé la fréquence des anticorps anti PLG-I chez des sujets d'un même foyer en contact avec l'infection et chez des témoins, en Corée et aux Philippines. En Corée (cas de lèpre: 0,04 pour 1000), la fréquence des anticorps anti PGL-I est respectivement de 4,8\% chez les sujets témoins et de $8,0 \%$ chez les sujets en contact. D'autre part, le taux de cas séro-positifs aux Philippines est de $10,8 \%$ chez les sujets témoins et de $13,4 \%$ chez les sujets en contact (cas de lèpre: 0,70 pour 1000). Une remarque intéressante a été faite concernant la nette différence dans la fréquence des anticorps anti PGL-I parmi les enfants: 10 à $14 \%$ chez les enfants de moins de 10 ans et 15 à $18 \%$ chex les enfants âgés de 10 à 19 ans aux Philippines, en comparaison avec $0 \%$ et 2,9 à $6,4 \%$ en Corée, respectivement. Cette étude semble donc indiquer qu'une fréquence élevée d'anticorps IgM anti PGL-I chez les enfants pourrait signifier une transmission active de $M$. leprae se traduisant par une augmentation de la lèpre parmi la population.

\section{El predominio de los anticuerpos IgM al glicolípido-I fenólico entre los contactós de domicilio y controles en Korea y las Filipinas}

\author{
Sang-Nae Cho, Seong Hwa-Kim, R V Cellona, Gertrude P Chan, \\ T FAJARDo, G P WALSH Y JOO-DEUK KiM
}

Resumen El glicolípido-I fenólico (PGL-1) es un antígeno específico para Mycobacterium leprae y los anticuerpos del antígeno sugieren una infección de $M$. leprae. Para comparar la transmisión de $M$. leprae entre diferentes populaciones, comparamos el predominio de anticuerpos IgM antiPGL-1 entre los contactos de domicilio y controles, entre Korea y las Filipinas. En Korea (con incidencia de lepra de 0,04 por mil), el predominio de anticuerpos antiPGL-1 era $4,8 \%$ en los controles y $8,0 \%$ en los contactos respectivamente. De otro lado, la seroincidencia en las Filipinas fue $10,8 \%$ en los controles y $13,4 \%$ en los contactos (con incidencia de lepra de 0,70 por mil). Es interesante que hay una diferencia notable en el predominio de anticuerpos antiPGL-1 entre los niños de los dos países: 10 a $14 \%$ de los niños de menos de 10 años de edad y 15 a $18 \%$ de los entre 10 y 19 años en la Filipinas, comparado con $0 \%$ y 2,9 a $6,4 \%$ en Korea, respectivamente. Por lo tanto, este estudio sugiero que el predominio más elevado de anticuerpos IgM antiPGL en los niños puede indicar una transmisión activa de $M$. leprae que resulta en una incidencia de lepra más elevada en la populación. 